\title{
Mediating Role of Work Engagement on the Impact of High Performance Work Practices, Service Recovery Performance and Life Satisfaction in Selected Restaurants in Turkish Republic of North Cyprus
}

\author{
Madgaline Enow Mbi Tarkang Mary (Corresponding Author) \\ Eastern Mediterranean University, Northern Cyprus, E-mail: tarkange86@gmail.com
}

Ruth Nange yunji

Eastern Mediterranean University, Northern Cyprus,

E-mail: achiriruth@yahoo.com

Rawan Alafeshat

Eastern Mediterranean University, Northern Cyprus,

E-mail: rawan.alafeshat@emu.tr.edu

Received: July 7, 2019 Accepted: August 2, 2019 Online published: August 12, 2019

doi:10.5296/ijhrs.v9i3.15256 URL: https://doi.org/10.5296/ijhrs.v9i3.15256

\begin{abstract}
Purpose - Drawing from social exchange theory, our study examine Work Engagement as a mediator of the impact of High Performance Work Practices on Service Recovery Performance and Life Satisfaction.

Design/methodology/approach - Data obtained from the employees in restaurants in Famagusta region in Turkish Republic of Northern Cyprus. Structural Equation Modeling was used as the main instrument analysis to test the propose relationships.
\end{abstract}

Findings - Work Engagement is one of the immediate outcomes of High performance work practices that engenders the performance of employee and effect on Service Recovery 
Performance and Life Satisfaction. The findings highlight the influence Work Engagement in the intermediate linkage between High performance work practices, Service Recovery Performance and Life Satisfaction.

Practical implications - Work Engagement is a critical variable activating customer-contact employees and performance outcomes. As a suggestion, management need to attract and retain customer-contact employees who are energetic, dedicated, and are absorbed by their work.

Originality/value - Most studies on service recovery has been done in Western countries, such as Asia and Australia but little known is in the Middle East, so North Cyprus was selected to be surveyed. Furthermore a comprehensive study of High performance work practices, Work Engagement, Service Recovery Performance and Life Satisfaction is yet to be investigated simultaneously in three cities in Turkish Republic of North Cyprus.

Keywords: High performance work practices (HPWP), Work engagement (WE), Service recovery performance (SRP), and Life satisfaction (LS)

\section{Introduction}

Today's effort of all organizations is to develop firm-level performance and their human capital via using high-performance work practices (Huselid, 1995). The target of High Performance Work Prentices is to enhance firm performance and beneficial individual outcomes (Jiang et al., 2012). According to the literature High Performance Work Practices is very useful. Based on the findings of karatepe and Vatankhah (2015), on flight attendance, it is stated that the organization can exhibit their predisposition to improve on the abilities and the awareness of their employees through High Performance Work Practices. It is cited that employees who are satisfied with their career will be able to respond to the changing demands of their various customers, thus solve their problem successfully. Also it is by stressing on the importance of employers focus on High performance work practices practice that leads to the motivation of employees to deliver quality services and show a successful service recovery performance. Service recovery performance is resolving a service failure to satisfy and meet customer expectations (Babakus et al., 2003).

The present study makes employed Work Engagement as a mediator between High Performance Work Prentices and some other work related outcomes particularly Service Recovery Performance and Life Satisfaction. There is just a handful of empirical research on Work Engagement in frontline service jobs in the hospitality management industry (Karatepe, 2014). For this reason Work Engagement is now treated as a top topic in every successful business and organizations of which the hospitality industry is not left out (Barkhuizen et al., 2014). As combs et al., (2006) stated, employee can be able to improve on their abilities, acquaintance, talents through High Performance Work Prentice and also this will help to motivate employees to be very confident in their performances during service delivery. Results from previous studies on Work Engagement have shown that employees who receive training, rewards and empowerment through High Performance Work Prentices will perform their tasks with lots of energy, vigor and dedication and they will be immersed or 
absorbed in their jobs (Karatepe, 2011).

Furthermore, it is obvious that the role service recovery play as strategy in service marketing is substantial. S1lber, et al (2009) thoroughly examined the efficiency of recovery strategies and found that recovery strategy was the most dominant strategy over other strategies in restaurant industry (Boshoff, 2000). An efficient Service Recovery Performance will result to increase customer satisfaction which will lead to positive word of mouth and loyalty. Till present, only a little is known with respect to the way frontline employees can improve on the performance of service recovery and also to contribute to the process of handling complaint brought by customers in a diligent manner. (Bal, et al., 2013). The present study associates High Performance Work practices, Service Recovery Performance and life satisfaction considering the mediating effect of Work Engagement. Employees who are interested and involve themselves in their job with pleasure are supposed to be very pleased with their job in particular and their life as a whole (Karatepe, 2010). Although some empirical research showed that employee's behavioral outcome (e.g., life satisfaction) are affected by Work Engagement, further empirical research needs to be carry out. The current studies make several contributions to the body of the literature. This study tries to test the effect of High Performance Work Practice on Service Recovery Performance and Life Satisfaction with Work Engagement as a mediator in these relationships. Most significantly, the present study seeks to test the indirect relationship between High Performance Work Prentice and Service Recovery Performance and Life Satisfaction through Work Engagement as a mediator. Studies have been done on service recovery in different parts of the globe, Asia and Australia (Wu et al 2018) and different sub- sectors in the service industry like flight attendants in Iran, (Karatepe and Vatankhay 2015), social media on customers in USA, (Jeong and Lee 2017) so far there have not been any study about employee service recovery in the above tree major cities in North Cyprus. Therefore this study will contribute to the literature on Service Recovery Performance in this part of Middle East. The definition of service recovery performance emphasizes two elements: whether employees are able to effectively resolve service failures (Boshoff and Allen, 2000) and how hard employees try to convert the negative emotions of customers into satisfaction. The latter comes with own capabilities and the actions they take (Babakus et al., 2003)It is important in Service Recovery Performance that frontline employees be capable to resolve a failure in service to gain satisfaction of their customers (Babakus et al., 2003). Regarding to literature this study used the Service Recovery Performance and Life Satisfaction for restaurants frontline employees who are dealing directly with customers and these employees are expected to fulfill the needs of these customers in order to retain them. The purpose of the present study is to examine the effect of high performance work practices on Service Recovery Practice and Life Satisfaction and the mediating role of Work Engagement in the above relationship. Service Recovery Prentice and Life Satisfaction is studied as performance outcome. In addition this study proposes a conceptual model to investigate the effect of High Performance Work Prentice on Service Recovery Performance and Life Satisfaction, on frontline employees in restaurants around the Famagusta Girne and Lefkosa cities in North Cyprus. 


\section{Theoretical Background and Hypotheses Development, and Research Model}

\subsection{Theoretical Background}

Every business organizations are involved in Social exchange relationships with their employees characterized as "subjective, in relationship-arrangement. Positive social exchange relationship, will enhance the employees work engagement and commitment (Lavell et al., 2007). There are many studies showing the relationships that exist in real life work environment and it implications to manager (Bass, 1990). It is believed that these relationships, with the manager or the organization will either have a positive or negative impact on the employees' attitudes to their work, the level of their engagement and performance Mowday et al (1982).

Evidence shows that all things being equal when employees perceived their employer to be committed in delivering High Performance Work Prentices, like: employees mentoring, current and flexible job description, employees' suggestion and flexible job description, regular performance appraisal, employees reward and award program, these employees will in-turn repay the employer back through hard work and improved performance (Karatepe, 2011 and Saks, 2006). Employees who do not feel motivated always have the tendency to leave their present organizations to a better one. Employees' involvement without any doubt leads to business success, through a well-managed process. Work Engagement is a positive, fulfilling work related state of mind which reflects how the employees approach their work with vigor, dedication and commitment, with a sign of inspiration and pride (Schaufeli et al., 2002). The research work will anchor on social exchange theory, which philosophically showed the relationship between employer and employees as a reciprocity in nature, embracing the economic and social implication of every organizational relationships either contractual or verbal (Gouldner,1960) These relationships reflects possibly the employees' life satisfaction which is personal evaluation of one's life presently and in the future.

\subsection{High Performance Work Prentices and Work Engagement}

High Performance Work Prentices involve job characteristics, which according to the AMO model, enhance employees' workplace abilities, improve employees' motivation to utilize their abilities, and provide opportunities for employees' to exercise discretionary effort. There is evidence to suggest a direct positive relationship between High Performance Work Prentices and employees' job satisfaction (Barling et al., 2003 ;) and work engagement (Bal et al., 2013). Rigorous selection practices enable current employees to understand how management pays attention to the acquisition of talented individuals and enhancement of service quality (Sun et al., 2007). Such employees receive continuous training to foster their technical and behavioral skills and learn how to use empowerment and work in teams successfully (Boshoff and Allen, 2000). Food service sector is a very unique one that can cause burn out and turn-off intention if workers are not engaged due to lack of High Performance Work Prentices, happy employees will make a happy customer, good relationship has been recognized as a vital key to developing customers' loyalty in any form of business of which food service is part. We therefore hypothesized: 
H1: High performance work practice is positively related to Work Engagement

\subsection{High Performance Work Practices and Life Satisfaction}

High performance work practices have a unique reflection on Life Satisfaction of employees. Life Satisfaction is affected by many factors and out of which the High performance work practices at the place of work is not left out. Employees spend most of the active hours of the day at the place of their jobs. The stress and the task of the job can make life unbearable if the employers refuse to carry out High performance work practices. In line with self-determinant theory, which informed that when employees' needs are met psychologically, it will enhance personal growth, organizational growth and citizenship (Deci and Ryan 2000). Employers should try as much as possible to enhance the employees life satisfaction through High Performance Work Practices which can also include both body and employment security, with the timely payment of their wages to meet their needs, if these are in place the workers will be happy, they will perform better, improve the profitability as revealed by Deaton (2008) that employment as one of the major domain of life satisfaction. The following hypothesis is proposed:

H2a: High performance work practice is positively related to Life satisfaction

\subsubsection{High Performance Work Practices and Service Recovery Performance}

High performance work practices are a group of separate but interconnected human resource practices which is use in business organizations to show the employers commitment to the welfare and carrier progression of the employees and to enhance their job engagement and performance High Performance Work Prentices ranges from employees training, performance appraisal compensation, good social relationship, all these without doubt are germane to employees perception of the employer and supervisor which is directly related to job outcome (Boselie et al., 2005 and). When these are in line Service Recovery Performance will be easier to carry out with the joint effort of the employees, since they are the one that attend to the customers and they know when the customers are happy or unhappy with the service they provide. It is important to have good high performance work practice, in order to improve attitudes, behaviors, performance of the employees (Messersmith et al., 2011). This is expected to bring a good and fast Service Recovery Performance to the business, the following hypothesis is proposed:

H2b: High performance work practice is positively related to Service Recovery Performance.

\subsubsection{Work Engagement and Life Satisfaction}

The thought of well-being can be analyzed in two angles, those being subjective or personal and mental. The personal wholeness among these thoughts somewhat compares to the decadent perspective foreseeing the person's avoidance away from torment and way to deal with delight, mental prosperity relates to guaranteeing the individual's self-improvement and understanding one's on possibilities (Sahranç, 2007). The idea of subjective prosperity, which investigates the people's good usage of each person's livelihood, comprises two portions, the people which have passionate and those with intellect (Diener in1984). Life Satisfaction 
indicate a psychological evaluation with respect to fulfillment by one's decision to stay in life, which indicates key pointer of personal prosperity and wellness (Linley et al., 2009 Positive feelings associated with work engagement may have spillover effects on general well-being, which affect life satisfaction (Hakanen \& Schaufeli, 2012) When people meet their goals in life, they feel very fulfilled and they become more inspired to go ahead with their lives notwithstanding adversities, hold back from intuition negative and disturbing musings, place themselves in others' shoes and never permit their intentions, hope, dreams in life to die, they will have high self-esteem in their lives which will guarantee them to feel self-sufficient Life satisfaction can be influenced by the working environment and the working conditions of employees, which can be enhanced by good High Performance Work Practices.

Work Engagement is a critical issue in the welfare of employees identified with their job, for example, laborers' stress, fulfillment alongside exhaustion. Several studies have reported that Work Engagement to have positive results for the employees, their family and the environment where they carry out their tasks, are identified with life fulfillment and predict the last in an emphatically significant way are consideration (De Cuyper et al., 2009). Research has shown that employees who are more engaged in their work have higher satisfaction levels (Caesens et al, 2014; Hakanen \& Schaufeli, 2012). An employee who is not satisfied will always find it hard to do anything meaningful Full engagement to job tasks for these types of employees will definitely be a fallacy. Food service organizations need workers that are committed and engaged in their work due to the nature of the enterprise. We therefore hypothesized that:

H3a: work engagement is directly link to Life Satisfaction.

\subsubsection{Work Engagement and Service Recovery Performance}

Administration recuperation alludes to the moves an organization makes because of an administrative disappointment with regards to customers' expectations (Grönroos, 1988). Enthusiasm for administration recuperation has developed on the grounds that terrible administration encounters regularly prompt customer dis-satisfaction (Keaveney, 1995). Service recovery is a crucial part of service in the hospitality industry. Meanwhile service failure is an inevitable reality and hospitality industry; employees must maintain customer satisfaction and loyalty after service failures (Liao, 2007). The behaviors of service employees often influence the relationship between service recovery performance and customer outcomes (Liao, 2007). For customers to be satisfied, employees must be engaged in the jobs so as to know what to do when to do and how to do it. Engagement is a motivational construct defined as a "positive, fulfilling, work-related state of mind that is characterized by vigor, dedication, and absorption" (Schaufeli et al., 2002). Work Engagement has been connected with occupation fulfillment, authoritative responsibility, individual activity, proactive conduct, learning inspiration, execution, administration quality, and specialty unit execution (Salanova et al., 2005). In the light of the given results, the current hypothesis is proposed:

H3b: work engagement is directly link to Service Recovery Prentice 


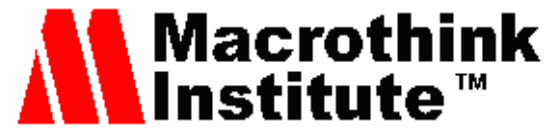

International Journal of Human Resource Studies

ISSN 2162-3058

2019, Vol. 9, No. 3

2.3.4 Work Engagement as a Mediator Between High Performance Work Practices, Life Satisfaction and Service Recovery Performance

Our study proposes that High performance work practice is related to Service Recovery Prentice and Life Satisfaction via Employee Engagement. In line with the attribution-based framework by Nishii et al., 2008, employees exhibit or demonstrate a positive result when they perceive managerial investments in human resources to promote service quality and care about their employees' well-being. As also put forward by the pathway of motivation in job demands-resources theory, High performance work practice plays a very significant role to motivate and enhance employees' work engagement (Bakker and Demerouti, 2017). These employees, successively, report affective and interactive consequences such as lower tendency to turn over and high levels of resourceful and extra-role performances. Also, Social exchange theory which is the basic theory of this study, presents a feasible hypothetical background for the mediation of High performance work practice and organizational performance relationships (Takeuchi et al., 2007). It has been confirmed in many studies, that Employee Engagement mediate many relationships. For example, a research on the banking sector in UK, Yalabik et al. (2013) showed that Employee Engagement mediated the relationship between job satisfaction and employee performance. Furthermore, Karatepe and Aga (2016) established that Employee Engagement fully mediated the relationships of organizational mission fulfillment and perceived organizational support with job performance among front employees in banks in Northern Cyprus. Additionally, an experimental investigation has showed Employee Engagement as a mediating factor in the relationship between High Prentice Work System practices and organizational performance. For example, Karatepe and Olugbade (2016) contended that High performance work practices, such as selective staffing, job security, teamwork, and career opportunities, impact job outcomes through Employee Engagement. Similarly, Karatepe (2013) found that Employee Engagement (i.e., vigor, dedication, and absorption) fully mediates the relationship between High Prentice Work System practices (i.e., training, empowerment, and rewards) and job and extra-role performance. There are many evidences on Employee Engagement as a mediator of the impact of High Prentice Work System or job resources on employee outcomes. For instance, Karatepe (2013) demonstrated that work engagement was a mediator between High Practice Work System and employees' task performance and extra-role customer service. In another study, it was reported that the impact of High Practice Work System on absence intentions, creative and service recovery performances was mediated again by Employee Engagement (Karatepe and Olugbade, 2016). Since many past studies as mentioned above investigated and confirmed Employee Engagement as a mediator in the above relationships, we can propose the following hypotheses:

H4a. Employee Engagement mediated the relationship between High performance work practices and Service Recovery Performance.

H4b. Employee Engagement mediated the relationship between High performance work practices and Life Satisfaction. 


\subsection{Conceptual Research Model}

The conceptual model of the current study as show in Diagram 1 explained the following proposed hypothesis. It supposed that the practices of high performance work practices have effect on Work Engagement. At the same time, the model displays that Work Engagement linked directly with Service recovery Performance and Life satisfaction as indicators of organization performance. Also; it proposes that work engagement mediate the effect of High performance work practice on both Service Recovery Performance and Life Satisfaction

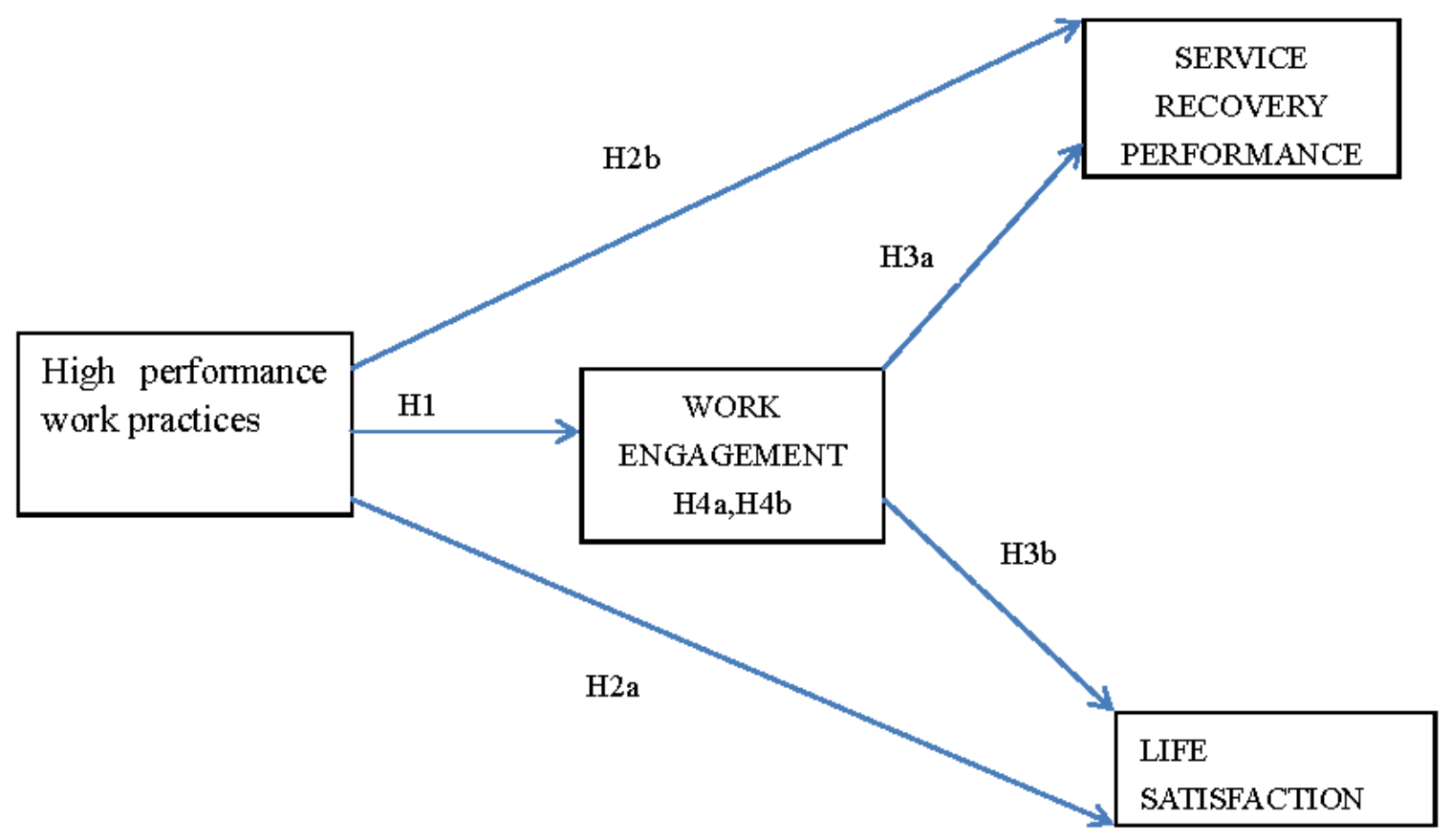

\section{Methodology}

\subsection{Sample and Procedure}

The present study developed four hypotheses, as we seen in the literature above. These hypotheses will be tested using data collected from the employees in restaurants of three regions; Famagusta, Girne and Lefkosa in Turkish Republic of Northern Cyprus (TRNC). The management or owners of these restaurants were contacted verbally, since most of them were available almost every day. Some were contacted through letters. These letters contained informations explaining the purpose of the study and to ask for permission to collect data from their employees, including frontline employees. This study selected the participants on basis of convenience sampling method, which is a non-probability sampling method. The questionnaires are designed in a way that identification of employees is not revealed in any way. Common method bias is a very essential problem in most quantitative studies and it gives high level measurements errors and this bias increases or decreases the actual correlation of the measurement constructs (Podsakoff et al,. 2003). The questionnaires were divided in to three parts; I, II and III and were collected in three different times, Time I, Time II and Time III, with an interval of one week. Time I questionnaires consists of demographic questionnaire such as age, education, marital status gender etc., and items for 


\section{Macrothink}

International Journal of Human Resource Studies

ISSN 2162-3058 2019, Vol. 9, No. 3

High performance work practice. Time II consist of items of work engagement and Time III consists of item measurements of both service recovery performance and life satisfaction.

\subsection{Measurements}

In agreement with back translation method (Brislin's, 1986), the questionnaire items for the three different times, Time I, Time II and Time were first written in English, then later translated to Turkish and then back translated to English by to make sure that both English and Turkish questionnaires were exactly comparable to each other theoretically. This translation and back-translation were done by native speakers who are perfect in both languages. A pretest was carried out on twenty frontline employees of these different restaurants to make sure the questionnaire items are easy to understand and also to test reliable before the final data collection. 300 questionnaires were distributed to the restaurants in the above mentioned regions

The current study selected several items to measure the study variables. For instance, to measure the High performance work practice practices the fifteen items were taken from Amin et al. (2014). Three indicators, namely vigor, deduction, and absorption, measured work engagement using nine items adapted from Schaufeli et al. (2006). Further, the study used seven items from Diener et al. (1985) to examine life satisfaction. Five items adapted from Boshoff and Allen (2000) was employed to measure service recovery performance. The responses to items related to high performance workpractices, SL and service recovery performance were rated on a 5-point scale ranging from strongly agree (5) to strongly disagree (1). Work engagement items were measured using a 7-point frequency rating ranging from always (7) to never (1).

\section{Results}

Table 1. Respondent's Profile

\begin{tabular}{ccc}
\hline Construct & Frequency & Parentage \% \\
\hline Male & Gender & \\
\hline Female & 168 & 60.6 \\
\hline $18-27$ & 109 & 39.4 \\
\hline $28-37$ & Age & \\
\hline $38-47$ & 95 & 34.3 \\
\hline & 116 & 41.9 \\
\hline
\end{tabular}




\begin{tabular}{|c|c|c|}
\hline 47-above & 13 & 4.7 \\
\hline \multicolumn{3}{|c|}{ Education level } \\
\hline Secondary and high school & 20 & 11.3 \\
\hline Two-year college degree & 60 & 33.9 \\
\hline Four-year college degree & 80 & 45.2 \\
\hline Graduate & 17 & 9.6 \\
\hline \multicolumn{3}{|c|}{ Marital status } \\
\hline Single & 94 & 53.1 \\
\hline Married & 70 & 39.6 \\
\hline Divorced & 13 & 7.3 \\
\hline \multicolumn{3}{|c|}{ Tenure } \\
\hline Under 1 year & 45 & 25.4 \\
\hline $1-5$ years & 100 & 56.5 \\
\hline $6-10$ years & 25 & 14.1 \\
\hline $11-15$ years & 7 & 4 \\
\hline
\end{tabular}

\subsection{Data Analysis}

This study employed Structural Equation Modeling (SEM) to test the hypothesis. According to (Hair et al., 2010), in the chi-square $\left(\chi^{2}\right)$ test, the chi-square to degrees of freedom ratio $\left(\chi^{2} / \mathrm{df}\right)$ must be less than three and the root mean square error of approximation (RMSEA) should be less than 0.08. The comparative fit index (CFI) should be more than 0.90 (Kline, 2015). Also, the current study used the Cronbach's alpha to confirm the reliability of all variables of the study (Nunnally and Bernstein, 1994). 
4.2 Measurement Results

Table 2. Results of Validity and Reliability Test

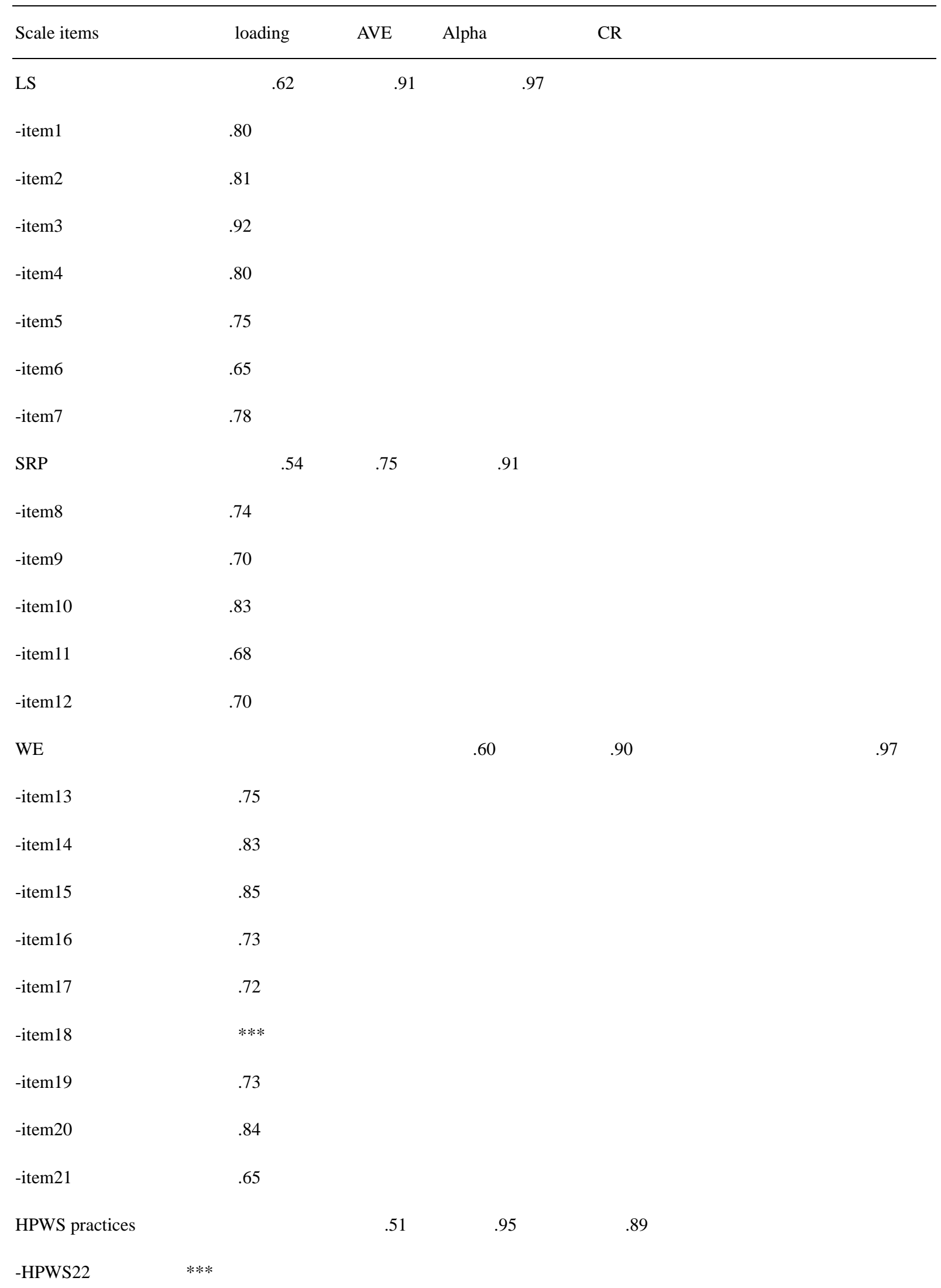




\begin{tabular}{ll}
-HPWS23 & $* * *$ \\
-HPWS24 & .65 \\
-HPWS25 & $* * *$ \\
-HPWS26 & .72 \\
-HPWS27 & .73 \\
-HPWS28 & .74 \\
-HPWS29 & .72 \\
-HPWS30 & .74 \\
-HPWS31 & .70 \\
-HPWS32 & .70 \\
-HPWS33 & .71 \\
-HPWS34 & .72 \\
-HPWS35 & .60 \\
\hline
\end{tabular}

The constructs of the proposed research model were analyzed using Confirmatory Factor Analysis (CFA). Furthermore, we also assessed the reliability and validity of the constructs. This study assessed the reliability using Cronbach's alpha and composite reliability (CR), (Bagozzi and Yi, 1988; Nunnally \& Bernstein 1994). Table 2 shows finding of factors loadings, Cronbach's alpha, composite reliability and AVE According to results above, coefficient alpha for each indicator was larger than the threshold of 0.70 , ranging from 0.75 to 0.95. Composite reliability for each latent variable was also above 0.60. Therefore measures were reliable, (Bagozzi and Yi, 1988; Nunnally, 1978) Then, the study assessed the convergent validity and discriminant validity by utilizing the average variance extracted (AVE) technique. Since none of the shared variances between pairs of constructs was larger than the average variance extracted by each latent variable, all variables were distinct from discriminant validity (Anderson \& Gerbing, 1988; Fornell \& Larcker, 1981. Three items from High performance work practices, and one from work engagement were dropped due to low loading. Therefore the results provided evidence for convergent and discriminant validity. 
Table 3. Correlation Results

\begin{tabular}{|c|c|c|c|c|c|c|c|}
\hline & Mean & & SD & & & 12 & 4 \\
\hline 1. LS & 3.90 & .869 & & - & & & \\
\hline 2. SRP & & 3.68 & .541 & $.513 * *$ & - & & \\
\hline 3. WE & & 4.1 & .810 & $.540 * *$ & $.501 * *$ & - & \\
\hline 4. HPWS practices & & 5.80 & .923 & $.480 * *$ & $.440 * *$ & $.520 * *$ & - \\
\hline
\end{tabular}

Note: $\mathrm{SD}=$ Standard deviation. $\quad * p<0.05 ; * * p<0.01$

Table 3 presents the results of the means, standard deviations and correlations for life stisfaction, Service recovery performance, work engagement, and High performance work practices. The results display that Life satisfaction is positively related to Service recovery performance $(\mathrm{r}=0.513, p<0.001)$, work engagement $(\mathrm{r}=0.540, p<0.001)$, and High performance work practices $(\mathrm{r}=0.480, p<0.001)$. Whereas service recovery performance was significant linked to work engagement $(\mathrm{r}=0.501, p<0.001)$, and High performance work practice $(\mathrm{r}=0.440, p<0.001)$. Also, High performance work practice was significant with work engagement $(\mathrm{r}=0.520, p<0.001)$. All values of correlation were less the cut-off of 0.70 .

\subsection{Structural Equation Model}

\begin{tabular}{|c|c|c|c|c|c|c|c|}
\hline Hypotheses Testing & & Std.Est & & S.E & \multicolumn{3}{|c|}{$C R$} \\
\hline$P$ & Results & & & & & & \\
\hline H1a: HPWS $\rightarrow$ SL & & 0.400 & & 0.0456 .22 & & 0.001 & \\
\hline \multicolumn{8}{|l|}{ Supported } \\
\hline H1b: HPWS $\rightarrow$ SRP & & 0.530 & & 0.0608 .11 & & 0.001 & \\
\hline \multicolumn{8}{|l|}{ Supported } \\
\hline $\mathrm{H} 2 \mathrm{HPWS} \rightarrow \mathrm{WE}$ & & 0.402 & & 0.0544 .50 & & 0.001 & \\
\hline \multicolumn{8}{|l|}{ Supported } \\
\hline $\mathrm{H} 3 \mathrm{a}: \mathrm{WE} \rightarrow \mathrm{SL}$ & 0.130 & & 0.061 & & 3.00 & & 0.001 \\
\hline \multicolumn{8}{|l|}{ Supported } \\
\hline $\mathrm{H} 3 \mathrm{~b}: \mathrm{WE} \rightarrow \mathrm{SRP}$ & 0.150 & & 0.091 & 2.10 & 0.001 & & \\
\hline Supported & & & & & & & \\
\hline
\end{tabular}

Note: Std. Est $=$ Standardized estimate, S.E $=$ Standard Error, C.R = Critical Ratio. 


\section{Macrothink}

International Journal of Human Resource Studies

ISSN 2162-3058

2019, Vol. 9, No. 3

The current study employed structural equation modeling to test the hypotheses. There were four-factor measurement model shown an acceptable data in the model analysis as follows $\left(\chi^{2}\right.$ $\left.=986.857, d f=478, \chi^{2} / \mathrm{df}=2.03, \mathrm{CFI}=0.902, \mathrm{RMSEA}=0.066\right)$. The $\chi^{2} / \mathrm{df}$ value of 2.03 is less than three, CFI was 0.902 which is more than 0.90 , and the value of RMSEA is less than 0.08 , all these results indicating an acceptable fit.

Table 4 presents the standardized estimates (Std.Est), standard errors (S.E) and significance levels $(p)$. Hypotheses $H I a$ and $H 1 b$, which proposed that High performance work practice was significant effects on life stisfaction and service recovery performance, $\beta=0.400$ $(p<0.001)$ and $\beta=0.530 \quad(p<0.001)$, respectively. High performance work practice also positively affected work engagement $(\beta=0.402, p<0.001)$, supporting $H 2$. Whereas, work engagement was significant impact on both life satisfaction $(\beta=0.130, p<0.001)$ and service recovery performance $(\beta=0.150, p<0.001)$. Therefore, $H 3 a$ and $H 3 b$ are supported.

Table 5. Path Estimates of Direct Effect Models

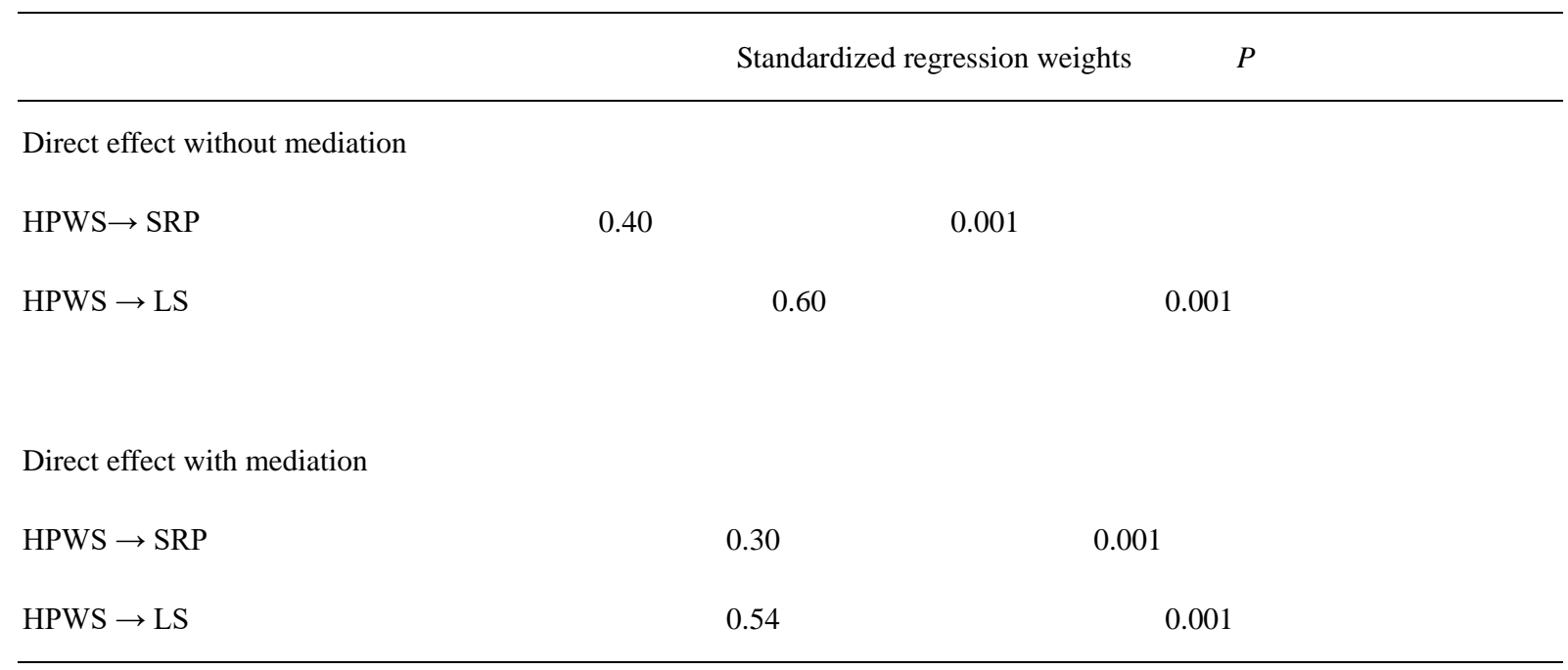

Table 5 provides path estimates of the direct impact models. The results illustrate that work engagement entered the model; the effect of High performance work practice on service recovery performance was reduced from standard estimate. $0.40(p=0.001)$ to $0.30(p=0.001)$, and the influence of High performance work practice on life satisfaction was decreased from standard estimate of $0.60(p=0.001)$ to $0.54(p=0.001)$. Thus, work engagement play a partial mediator role, and $H 4 a$ and $H 4 b$ are supported.

\section{Discussion and Conclusion}

Our study proposed and tested the empirical model that examined EE as a mediator of the impact of High performance work practices on Service recovery performance, and life satisfaction. Data obtained from the employees in restaurants in Famagusta, Girne and Lefkosa regions in North Cyprus.

We found evidence as shown in the results above that High performance work practice are 
directly and positively related work engagement, This evidence corroborates reports that a coherent bundle of human resource management practices might encourage positive employee attitudes behaviors and possible performances, (Macky \& Boxall, 2007; Bal et al., 2013) When an extensive range of human resource management practices are used together in combination, they generate mutually supportive effects that shape the quality of employees' functioning at work (Van De Voorde et al., 2012)

The results suggest that High performance work practice is an immediate consequence of Service recovery performance. Thus, it is important to have a good High performance work practices, in order to improve attitudes, behaviors, performance of the employees (Messersmith et al., 2011). In additional, the High performance work spractices foster the life satisfaction. High performance work practice is of the immediate factor effect on employee performance and their satisfaction when the employee perceive the practices of High performance work practices such as training and development practice to increase the level of their skills and performance effect on life satisfaction. Thus, management should try as much as possible to enhance the employees life satisfaction through High performance work practice which can also include both body and employment security, with the timely payment of their wages to meet their needs, if these are in place the workers will be happy, they will perform better, improve the profitability as revealed by Deaton (2008) that employment as one of the major domain of life satisfaction.

Our study proposes that High performance work practice is related to service recovery performance and life satisfaction via work engagement. The results suggest that significant positive impacts of High performance work practices on service recovery performance, and life satisfaction. Furthermore, results show a positive effect between work engagement and service recovery performance and life satisfaction. According to (Hakanen et al. 2012), work engagement positively predicted positive work-family enrichment, suggesting positive excitements and assertiveness related to work engagement which in turn spill over to personal life contributing to general well-being. More concisely engaged employees draw upon many resources, easily caught in a gain spiral, which also produces context-free, general well-being. Satisfying complaining customers is challenging, especially when dealing with the increasing number of customers with culturally diverse backgrounds.

The results supports a positive effect of work engagement on service recovery performance. This implies that culturally intelligent employees provide better service recovery, because they are more engaged. We also provide empirical support for the framework of Van Vaerenbergh and Orsingher's (2016), which posits that personal resources influence service recovery performance through work engagement.

Our findings indicate that work engagement partially mediates the relationships of both High performance work practices with service recovery performance, and Life satisfaction. As hypothesized, work engagement mediates the impact of High performance work practices on service recovery performance and life satisfaction. Many past researches have confirmed the mediating effect of work engagement in many relationships. For example, from the viewpoint of mediation, work engagement may be a crucial mediator in the link between High 
performance work practices and service recovery performance and Life satisfaction. This is concurrent with past studies that treated and confirmed work engagement as a mediator and examined its antecedents and outcomes (Arasli et al., 2017; Cain et al., 2018). The presence of High performance work practices, practices improves work engagement that in turn engenders high levels of performance of employees and Life satisfaction. The presence of work engagement in the model decreases the effect of high performance work practice on service recovery performance and Life satisfaction. This indicate that E work engagement acts as a partial mediator between the above relationship

\subsection{Conclusions}

This present study which aimed to examine the effect of High performance work practices on work engagement, and work engagement effect on service recovery performance and Life satisfaction in restaurants in north Cyprus, has shown that High performance work practices,, which can be seen as a coherent package human resource practices, influence employee outcomes, like work engagement as the case of this study. The study also shows that work engagement also influences service recovery performance and Life satisfaction. High performance work practice reduce the levels of staff absenteeism, which is seen in the way they engage in their tasks. The study also confirmed that work engagement is positively related to service recovery performance. Employees that are engaged show high level of dedication and they are always physically and mentally absorbed to their jobs. These type of employees are very sensitive to negative feedbacks that customers can express and as such they are always prompt and on time to amend recover these types of situations to the satisfaction of the guests.

Work-related states of mind such as work engagement, will predict life satisfaction in the long-term. Basically, workplace interventions and investments in High performance work practice will foster work engagement which extend their influence beyond work and build general well-being among employees leading to Life satisfaction. Therefore we can conclude that when service organizations invest in High performance work practices, schemes they foster engaged employees who are knowledgeable when it comes to recovering from a poor service. Their engagement in their job will also make them comfortable and happy which spills over to their personal lives.

\subsection{Implications}

According to our study and many past literature, work engagement is a critical variable activating customer-contact employees and performance outcomes As a suggestion management need to attract and retain customer-contact employees who are energetic, dedicated, and are absorbed by their work. Work-engaged employees are ready to learn more and contribute to the organization. To do this, management can take advantage of high human resources practices such as continuous training, empowerment, rewards, and work-life balance. Employer is able to carry out High performance work practices relevant to their operations. The employer among other things should be involve in good compensation system, embracing of suggestion from employees through adequate communication, calibrated job classification system and training (Noe et al., 2007). Creating a work 
environment where front employees can come up with fresh perspectives for service improvement and give suggestions about the solution of fresh problems in service delivery process will be helpful. The presence of such an environment is likely to foster their service recovery.

\subsection{Limitations}

The present study highlighted a number of limitations that can be considered for future research purposes. First, data that collected from the employees in restaurants of three regions Famagusta, Girne and Lefkosa in Turkish Republic of Northern Cyprus might limit the generalizability of the findings. Therefore, future research should collect data from different service industries in the region. (e.g., airline and banks) in different countries.

\section{Reference}

Amin, M., Khairuzzaman, W., Ismail, W., Zaleha, A., Rasid, S., Daverson, A., \& Selemani, R. (2014). The impact of human resource management practices on performance: Evidence from a Public University. The TQM Journal, 26(2), 125-142.

https://doi.org/10.1108/TQM-10-2011-0062

Anderson, J. C., \& Gerbing, D. W. (1988). Structural equation modeling in practice: A review and recommended two-step approach. Psychological Bulletin, 103(3), 411-423.

https://doi.org/10.1037/0033-2909.103.3.411

Andrews, F. M., \& Withey, S. B. (1976). Social indicators of wellbeing: America's perception of life quality. New York: Plenum Press. https://doi.org/10.1007/978-1-4684-2253-5

Ashill, N. J., Rod, M., \& Carruthers, J. (2008). The effect of management commitment to service quality on frontline employees' job attitudes, turnover intentions and service recovery performance in a new public management context. Journal of Strategic Marketing, 16(5), 437-462. Association, Washington, DC, 290-312.

https://doi.org/10.1080/09652540802480944

Babakus, E., Yavas, U., Karatepe, O. M., \& Avci, T. (2003). The effect of management commitment to service quality on employees' affective and performance outcomes. Journal of the Academy of marketing Science, 31(3), 272-286.

https://doi.org/10.1177/0092070303031003005

Bagozzi, R. P., \& Yi, Y. (1988). On the evaluation of structural equation models. Journal of the academy of marketing science, 16(1), 74-94. https://doi.org/10.1007/BF02723327

Bakker, A. B., \& Demerouti, E. (2017). Job demands-resources theory: taking stock and looking forward. Journal of Occupational Health Psychology, 22(3), 273.

https://doi.org/10.1037/ocp0000056

Bakker, A. B., Hakanen, J. J., Demerouti, E., \& Xanthopoulou, D. (2007). Job resources boost work engagement, particularly when job demands are high. Journal of Educational Psychology, 99, 274-284. https://doi.org/10.1037/0022-0663.99.2.274 
Bal, P. M., de Lange, A. H., Zacher, H., \& Van der Heijden, B. I. (2013). A lifespan perspective on psychological contracts and their relations with organizational commitment. European Journal of Work and Organizational Psychology, 22(3), 279-292. https://doi.org/10.1080/1359432X.2012.741595

Barkhuizen, N., Rothmann, S., \& Van De Vijver, F. J. (2014). Burnout and work engagement of academics in higher education institutions: Effects of dispositional optimism. Stress and Health, 30(4), 322-332.

Barling, J., Kelloway, E. K., \& Iverson, R. D. (2003). High-quality work, job satisfaction, and occupational injuries. Journal of applied psychology, 88(2), 276.

Bass, Bernard M. (1990). From Transactional to Transformational Leadership: Learning to Share the Vision Organizational Dynamics. https://doi.org/10.1016/0090-2616(90)90061-S

Boselie, P., Dietz, G., \& Boon, C. (2005). Commonalities and contradictions in HRM and performance research. Human Resource Management Journal, 15(3), 67-94.

https://doi.org/10.1111/j.1748-8583.2005.tb00154.x

Boshoff, C., \& Allen, J. (2000). The influence of selected antecedents on frontline staff's perceptions of service recovery performance. International Journal of Service Industry Management, 11(1), 63-90. https://doi.org/10.1108/09564230010310295

Boshoff, C., \& Allen, J. (2000). The influence of selected antecedents on frontline staff's perceptions of service recovery performance. International Journal of Service Industry Management, 11(1), 63-90. https://doi.org/10.1108/09564230010310295

Brislin, R. W. (1986). The wording and translation of research instruments.

Combs, J., Liu, Y., Hall, A., \& Ketchen, D. (2006). How much do high-performance work practices matter? A meta-analysis of their effects on organizational performance. Personnel Psychology, 59(3), 501-528. https://doi.org/10.1111/j.1744-6570.2006.00045.x

De Cuyper, N., Notelaers, G., \& De Witte, H. (2009). Transitioning between temporary and permanent employment: A two-wave study on the entrapment, the stepping stone and the selection hypothesis. Journal of Occupational and Organizational Psychology, 82, 67-88. https://doi.org/10.1348/096317908X299755

Deaton, A. (2008). Income, Health and Well-Being around the World: Evidence from the Gallup World Poll. Journal of Economic Perspectives, 22(2), 53-72. https://doi.org/10.1257/jep.22.2.53

Deci, E. L., \& Ryan, R. M. (2000). The 'what' and 'why' of goal pursuits: Human needs and the self-determination of behavior. Psychological Inquiry, 11(4), 227-268.

Diener, E. (1984). Subjective well-being. Psychological Bulletin, 95, 542-575. https:// doi.org/10.1037/0033-2909.95.3.542

Diener, E., Emmons, R. A., Larsen, R. J., \& Griffin, S. (1985). The satisfaction with life scales. Journal of Personality Assessment, 49(1), 71-75. 
https://doi.org/10.1207/s15327752jpa4901_13

Food and Drug Administration. (2009). FDA report on the occurrence of foodborne illness risk factors in selected institutional foodservice, restaurant, and retail food store facility types.

Fornell, C., \& Larcker, D. F. (1981). Evaluating structural equation models with unobservable variables and measurement error. Journal of Marketing Research, 18(1), 39-50.

https://doi.org/10.1177/002224378101800104

Gouldner, A. W. (1960). The norm of reciprocity: A preliminary statement. American sociological review, 161-178.

Gronroos, C. (1988). Service quality: The six criteria of good perceived service. Review of business, 9(3), 1.

Guerci, M., Montanari, F., Scapolan, A., \& Epifanio, A. (2016). Green and nongreen recruitment practices for attracting job applicants: exploring independent and interactive effects. The International Journal of Human Resource Management, 27(2), 129-150.

https://doi.org/10.1080/09585192.2015.1062040

Hair, J. F., Black, W. C., Babin, B. J., \& Anderson, R. E. (2010). Advanced diagnostics for multiple regression: A supplement to multivariate data analysis.

Hakanen, J. J., \& Schaufeli, W. B. (2012). Do burnout and work engagement predict depressive symptoms and life satisfaction? A three-wave seven-year prospective study. Journal of affective disorders, 141(2-3), 415-424.

https://doi.org/10.1016/j.jad.2012.02.043

Huselid, M. A. (1995). The impact of human resource management practices on turnover, influence organizational outcomes? A meta-analytic investigation of mediating mechanisms.

Jeong, M., \& Lee, S. A. (2017). Do customers care about types of hotel service recovery efforts? An example of consumer-generated review sites. Journal of Hospitality and Tourism Technology, 8(1), 5-18. https://doi.org/10.1108/JHTT-09-2016-0049

Jiang, K., Lepak, D. P., Hu, J., \& Baer, J. C. (2012). How does human resource management influence organizational outcomes? A meta-analytic investigation of mediating mechanisms. Academy of management Journal, 55(6), 1264-1294

Karatepe, O. (2013) High-performance work practices and hotel employee performance:The mediation of work engagement. International Journal of Hospitality Management, 32(2013) $132-140$.

Karatepe, O. M. (2011). Procedural justice, work engagement, and job outcomes: evidence from Nigeria. Journal of Hospitality Marketing and Management, 20(8), 855-878.

Karatepe, O. M. (2013). High-performance work practices, work social support and their effects on job embeddednessand turnover intentions. International Journal of Contemporary Hospitality Management, 25(6), 903 - 921. https://doi.org/10.1016/j.ijhm.2012.05.003 
Karatepe, O. M., \& Aga, M. (2012). Work engagement as a mediator of the effects of personality traits on job outcomes: A study of frontline employees. Services Marketing Quarterly, 33(4), 343-362

Karatepe, O. M., \& Vatankhah, S. (2015). High-performance work practices, career satisfaction, and service recovery performance: a study of flight attendants. Tourism Review, 70(1), 56-71. https://doi.org/10.1108/TR-01-2014-0004

Keaveney, S. M. (1995). Customer Switching Behavior in Service Industries: An Exploratory Study. Journal of Marketing, 58(April), 71-82.

Keser, A. (2005). İş doyumu ve yaşam doyumu ilişkisi: Otomotiv sektöründe bir uygulama. Çalışma ve Toplum, 4(1), 77-95.

Kim, H. J., Tavitiyaman, P., \& Kim, W. G. (2009). The effect of management commitment to service on employee service behaviors: the mediating role of job satisfaction .Journal of Hospitality and Tourism Research, 33(3), 369-390.

https://doi.org/10.1177/1096348009338530

Kim, T., Jung-Eun Yoo, J., \& Lee, G. (2012). Post-recovery customer relationships and customer partnerships in a restaurant setting. International Journal of Contemporary Hospitality Management, 24(3), 381-401.

Kline, R. B. (2015). Principles and practice of structural equation modeling (4th ed.).New York: The Guilford Press. https://doi.org/10.1108/09596111211217879

Lavelle, J. J., Rupp, D. E., \& Brockner, J. (2007). Taking a multifoci approach to the study of justice, social exchange, and citizenship behavior: The target similarity model. Journal of management, 33(6), 841-866. https://doi.org/10.1177/0149206307307635

Liao, H. (2007). Do it right this time: The role of employee service recovery performance in customer-perceived justice and customer loyalty after service failures. Journal of applied psychology, 92(2), 475. https://doi.org/10.1037/0021-9010.92.2.475

Linley, P. A., Maltby, J., Wood, A. M., Osborne, G., \& Hurling, R. (2009). Measuring happiness: The higher order factor structure of subjective and psychological well-being measures. Personality and individual differences, 47(8), 878-884.

Macky, K., \& Boxall, P. (2007). The relationship between 'high-performance work practices' and employee attitudes: an investigation of additive and interaction effects. The International Journal of Human Resource Management, 18(4), 537-567.

Maxham III, J. G. (2001). Service recovery's influence on consumer satisfaction, positive word-of-mouth, and purchase intentions. Journal of business research, 54(1), 11-24.

https://doi.org/10.1016/S0148-2963(00)00114-4

Messersmith, J. G., Patel, P. C., Lepak, D. P., \& Gould-Williams, J. S. (2011). Unlocking the black box: Exploring the link between high-performance work systems and performance. Journal of Applied Psychology, 96(6), 1105. 


\section{Mll Macrothink}

International Journal of Human Resource Studies

ISSN 2162-3058

2019, Vol. 9, No. 3

Mowday, R., Porter, L., \& Steers, R. (1982). Employee-organization linkages: The psychology of commitment, absenteeism, and turnover. New York: Academic Press.

Nishii, L. H., Lepak, D. P., \& Schneider, B. (2008). Employee attributions of the "why" of HR practices: Their effects on employee attitudes and behaviors, and customer satisfaction. Personnel psychology, 61(3), 503-545.

https://doi.org/10.1111/j.1744-6570.2008.00121.x

Noe, R. A., Hollenbeck, J. R., Gerhart, B., \& Wright, P. M. (2007). Fundamentals of human resource management.

Nunnally, J. C., \& Bernstein, I. H. (1994).Validity. Psychometric theory, 99-132.

Palmer, B., Donaldson, C., \& Stough, C. (2002). Emotional intelligence and life satisfaction. Personality and individual differences, 33(7), 1091-1100.

https://doi.org/10.1016/S0191-8869(01)00215-X

Podsakoff, P. M., MacKenzie, S. B., Lee, J. Y., \& Podsakoff, N. P. (2003). Common method biases in behavioral research: A critical review of the literature and recommended remedies. Journal of applied psychology, 88(5), 879.

https://doi.org/10.1037/0021-9010.88.5.879

Rod, M., \& Ashill, N. J. (2010). Management commitment to service quality and service recovery performance: a study of frontline employees in public and private hospitals. International Journal of Pharmaceutical and Healthcare Marketing, 4(1), 84-103. https://doi.org/10.1108/17506121011036042

Sahranç, Ü. (2007). Stres kontrolü, genel öz-yeterlik, durumluk kaygı ve yaşam doyumuyla ilişkili bir akış modeli. Yayımlanmamış Doktora Tezi, Gazi Üniversitesi, Ankara.

Saks, A. M. (2006). Antecedents and consequences of employee engagement. Journal of Managerial Psychology, 21(7), 600-619. https://doi.org/10.1108/02683940610690169

Salanova, M., Agut, S., \& Peiro, J. M. (2005). Linking organizational resources and work engagement to employee performance and customer loyalty: The mediating role service climate. Journal of Applied Psychology, 90, 1217-1227.

https://doi.org/10.1037/0021-9010.90.6.1217

Schaufeli, W. B., Bakker, A. B., \& Salanova, M. (2006). The measurement of work engagement with a short questionnaire: A cross-national study. Educational and Psychological Measurement, 66, 701-716.

Schaufeli, W. B., Martinez, I., Marques-Pinto, A., Salanova, M., \& Bakker, A. (2002a). Burnout and engagement in university students: A cross-national study. Journal of Cross-cultural Studies, 33, 464-481.

Schaufeli, W. B., Salanova, M., González-Romá, V., \& Bakker, A. B. (2002). The measurement of engagement and burnout: A two sample confirmatory factor analytic approach. Journal of Happiness studies, 3(1), 71-92. 
https://doi.org/10.1023/A:1015630930326

Silber, I., Israeli, A., Bustin, A., \& Zvi, O. B. (2009). Recovery strategies for service failures: The case of restaurants. Journal of Hospitality Marketing \& Management, 18(7), 730-740.

Smith, A. K., Bolton, R. N., \& Wagner, J. (1999). A model of customer satisfaction with service encounters involving failure and recovery. Journal of marketing research, 36(3), 356-372. https://doi.org/10.1177/002224379903600305

Sobel, M. E. (1982), “Asymptotic confidence intervals for indirect effects in structural equation. Sociological Review, 25(2), 161-178. https://doi.org/10.2307/270723

Sun, L. Y., Aryee, S., \& Law, K. S. (2007). High-performance human resource practices, citizenship behavior, and organizational performance: A relational perspective. Academy of management Journal, 50(3), 558-577. https://doi.org/10.5465/amj.2007.25525821

Takeuchi, R., Lepak, D. P., Wang, H., \& Takeuchi, K. (2007). An empirical examination of the mechanisms mediating between high-performance work systems and the performance of Japanese organizations. Journal of Applied psychology, 92(4), 1069.

https://doi.org/10.1037/0021-9010.92.4.1069

Van De Voorde, K., Paauwe, J., \& Van Veldhoven, M. (2012). Employee well-being and the HRM-organizational performance relationship: a review of quantitative studies. International Journal of Management Reviews, 14(4), 391-407.

https://doi.org/10.1111/j.1468-2370.2011.00322.x

Van Vaerenbergh, Y., \& Orsingher, C. (2016). Service recovery: An integrative framework and research agenda. Academy of Management Perspectives, 30(3), 328-346.

https://doi.org/10.5465/amp.2014.0143

Wu, W. Y., Qomariyah, A., Sa, N. T. T., \& Liao, Y. (2018). The Integration between Service Value and Service Recovery in the Hospitality Industry: An Application of QFD and ANP. International Journal of Hospitality Management, 75, 48-57.

https://doi.org/10.1016/j.ijhm.2018.03.0106

Yalabik, Z. Y., Popaitoon, P., Chowne, J. A., \& Rayton, B. A. (2013). Work engagement as a mediator between employee attitudes and outcomes. The International Journal of Human Resource Management, 24(14), 2799-2823. https://doi.org/10.1080/09585192.2013.763844

Zeithaml, V. A., Berry, L. L., \& Parasuraman, A. (1996). The behavioral consequences of service quality. Journal of marketing, 60(2), 31-46. https://doi.org/10.2307/1251929

\section{Copyright Disclaimer}

Copyright for this article is retained by the author(s), with first publication rights granted to the journal.

This is an open-access article distributed under the terms and conditions of the Creative Commons Attribution license (http://creativecommons.org/licenses/by/4.0/). 